\title{
Transformation pathways of phasing out coal-fired power plants in Germany
}

\author{
Stefan Vögele ${ }^{1 *} \mathbb{D}$, Paul Kunz ${ }^{1}$, Dirk Rübbelke ${ }^{2}$ and Theresa Stahlke ${ }^{2}$
}

\begin{abstract}
Background: While there are plenty of studies investigating the market penetration of new technologies, phaseout processes of a predominant technology are rarely analyzed. The present study explores the case of a declining technology, employing the example of coal-fired power plants in Germany. These plants were promoted by governmental decision-makers as well as by the industry for a long time, but meanwhile, the phase-out or at least a cutback of coal-fired power plants is--not only in Germany--considered to be a key strategy for the transformation towards a sustainable society.

Methods: We investigate potential pathways of the future development of the coal-fired power plant sector in an extended multi-level perspective (MLP) framework that integrates economic, social, political, and technical aspects.

Results: Taking into account the fact that coal is losing its support from several important stakeholders (e.g., governmental decision-makers, utilities) due to, e.g., changes in the prioritization of political goals, changes in the economic framework, in actor constellations, and in public attitudes, coal-fired power plants tend to be pushed into niches or to disappear completely.

Conclusions: A reasonable management of the niche technology "coal-fired power plants" could include a protection of space for ensuring a smooth removal of the links between the regime and the technology with respect to, e.g., social and environmental aspects. The phase-out pathways for the coal-fired power plants elaborated on in this paper help to better inform policy-makers to design transformation processes not only for coal-fired power but also for other declining technologies.
\end{abstract}

Keywords: Multi-level perspective, Coal-fired power plants, Phase-out, Transformation pathways

\section{Background}

The market penetration of a new technology strongly depends on its economic competitiveness. Changes in technological, political, economic, and social frameworks may bring about technological changeovers, in particular when there is limited adaptability of prevailing technologies to these changes. In such changeover processes, firms and other agents are looking for those technologies that fit the existing selection environment best and, with it, windows of opportunities for one technology might correspond to windows of threats for others (see, e.g., $[1,2])$. Lock-in and path dependence shape the size and design of the windows (see, e.g., [3, 4]). Most studies on respective transformation processes focus on the

\footnotetext{
* Correspondence: s.voegele@fz-juelich.de

${ }^{1}$ Forschungszentrum Jülich, Institute of Energy and Climate Research -

Systems Analysis and Technology Evaluation (IEK-STE), 52425 Jülich, Germany Full list of author information is available at the end of the article
}

evolution of new technologies' market penetration and omit future perspectives for the initially predominant technologies (see, e.g., [5]).

The multi-level perspective approach (MLP) (see, e.g., [5-7]) is a concept frequently employed to explore transformation processes such as the replacement of horse-drawn carriages by automobiles [8] and the replacement of sailing ships by steamships [9]. Also technologies that could become a key technology in the future were investigated in this way; examples are hydrogen and battery vehicles (see, e.g., $[10,11])$. Verbong and Geels [12], Verbong et al. [13], and Rosenbloom and Meadowcroft [14] analyze decarbonization pathways focusing not only on one specific technology but on a complex energy system. Newly emerging technologies and predominant technologies tend to co-evolve in such a way that the initially predominant technologies lose 
market power and/or political support and phase-out, while newly emerging technologies develop contrarily to this [15]. In contrast to approaches focusing on techno-economic systems, path dependencies and path creation, and transition management (see, e.g., $[6,16])$ in the MLP approach evolutionary aspects (e.g., disruptive changes in the general conditions or changes in attitudes and behavior) are taken into consideration. Besides the mapping of dynamics, the MLP approach shows similarities to innovation system approaches (i.e., with respect to actor and framework constellations for innovation processes). One of the key features of MLP is the consideration of a broad range of factors, which trigger the development of novelties and their dissemination. Hence, MLP differs significantly from techno-economic approaches, which focus on economic aspects and technological constraints.

In our study, we focus on the development of coalfired power plants in Germany. Since the development in the power plant sector is strongly influenced by manifold factors (e.g., attitudes of investors and public, decisions of policy-makers, disruptive changes resulting from developments on global or European level), we select MLP as the most appropriate approach.

The original perspective of the MLP approach is not concerned with "phasing out" processes. Instead, the focus is on innovations and their interference with the regime. In contrast, our study explores how a presently predominant technology becomes fainter and which transition pathways are possible. To put it differently, we are concerned with the question how this technology will "phase-out." A phase-out in our context means a process, which is initiated by many factors while a political program for it is not mandatory. We focus on the saturation and decline stage of coal-fired power plants and consider economic, social, political, and technical aspects. The objective of this case study is to improve the understanding of different transition pathways of a predominant but faltering technology. The results of this study will help to inform policy-making in this context. Coal-fired power plants are a very prominent example--not only in Germany (see, e.g., [17])--because their phase-out is considered to be a key strategy for the decarbonization of economies and the creation of sustainable societies [18]. A prerequisite for meeting the Paris Agreement goals of keeping a global temperature rise this century at least well below $2{ }^{\circ} \mathrm{C}$ above pre-industrial levels is seen by several studies in a rapid decline in the use of coal-fired power plants and a complete phase-out around mid-century globally (see [19]). Recently, the phase-out process got a new impetus by the establishment of the Powering Past Coal Alliance. Several countries, among them industrialized countries (e.g., the UK) as well as developing countries (e.g.,
Mexico), launched this alliance on 16th of November 2017, which strives for a phase-out of coal-fired power plants. The participating countries "commit to achieve a phase-out in an environmental, social, and economically inclusive way, including appropriate support for workers and communities" in their declaration [20]. ${ }^{1}$

Because of the importance of coal-fired power plants for lignite mining regions as well as for their reliability with respect to assured power capacity, the phase-out of coal-fired power plants has to be well planned (see, e.g., [21]). Phasing out coal-fired power plants will not only result in less $\mathrm{CO}_{2}$ emissions but will also affect the use of fresh water, ${ }^{2}$ the structure of the electricity grid, tax revenues on the local level, public research and development (R\&D) infrastructure (see, e.g., [22]) as well as international trade. On the other side, coal-fired power are increasingly faced by problems of acceptance which trigger the pressure on phasing out processes [23].

Since several coal-fired power plants are used as combined heat and power (CHP) stations, the supply of district heat will be affected by the phase-out of coal-fired power plants, too [24]. Thus, in order to avoid disruptions in the heat supply, pathways for the replacement of coal-fired CHP have to be developed.

On the local level, the shutting down of coal-fired power plants could have severe impacts on employment. Beside effects resulting from releasing staff working in power plants and mines, there will also be indirect effects resulting from a lower demand for goods and services needed for running the power plants as well as income effects [25]. For instance, local communities face lower incomes as a decline in profits of companies impairs tax revenues. Yet, in some strongly affected local communities (e.g., those located close to brown-coal pits) in particular, power from coal-fired plants is becoming less and less accepted.

The phase-out of coal-fired power plants is an even greater challenge due to the increasing domination of the electricity market by wind and PV power plants. Since wind conditions and solar radiation fluctuate over time, the applicability of wind and PV power stations for covering electricity demand at any time is limited whereas due to their high technological availability and flexibility, coal-fired power plants fulfill the requirement of "covering electricity demand at any point in time" without significant problems.

Possible futures for coal-fired power plants in Germany were identified and analyzed in several studies. Usually, the studies focus on the impacts of exogenously given reduction targets for greenhouse gas emissions or phase-out paths for coal-fired power plants (see, e.g., [26-28]). Typically, technology-based bottom-up models have been applied. Hence, scenarios reflect how the energy system will evolve from a technological point of view, aspects of 
lacking acceptance of coal-fired power plants are considered as bounds [29]. Other non-technological aspects, which have influenced the development of the German energy system in the past, are more or less ignored. Among these aspects are changes in $R \& D$ activities, in actor constellations (including coming up of pressure groups and changes in the mix of actors in power plant industries), feedbacks of public attitudes on the policies framework and vice versa, as well as disruptive impacts from global and European level. Hence, the landing process of a technology when being phased out of the regime, as well as non-technological aspects framing the phase-out process are not considered [30,31]. As an example of a soft landing process, which is strongly governed by factors, which are not considered in bottom-up models, the German nuclear phase-out can be used.

Since the ongoing processes in the power plant sector in Germany cannot be seen as a pure technological substitution process, the MLP approach is a suitable tool for the analysis of the process of pushing back coal-fired power plants into a niche area in Germany and possible pathways for their transition, as it allows for an inclusion of aspects that are beyond the technological sphere. The analysis will contribute to a better understanding of different transition pathways of a predominant but faltering technology.

The paper is organized as follows: The key elements of the employed research method are presented in section "Theoretical background." In the section "Methods," we provide information on the incorporation of the data used for the case study. In the section "Results and discussion," we conduct the analysis and provide detailed information on transition pathways for the sector of coal-fired power plants in Germany. The last section concludes and provides scope for further research.

\section{Theoretical background}

In contrast to merely technology- and market-based approaches, which one usually uses for describing the coming up and diffusion of technologies (e.g., [26, $32])$, the MLP approach more strongly integrates also political, social, and environmental dimensions of transformation dynamics. The emergence and dissemination of novelties including aspects of repressions of existing structures are explained by paying attention to changes in factors like, e.g., the overall framework and actor constellations. Thus, it is taken into consideration that technological changes do not result only from changes in cost (in combination with technological restrictions) but also from the interaction of a broad range of factors (like social acceptance, regulations, industrial, and infrastructural framework). By considering changes in the use of technology mixes as a result of evolution and coevolution of multidimensional factors, the MLP is particularly suitable for an analysis of complex socio-economic systems such as the transition of the German energy system.

Within the MLP, the elements of the system under consideration are assigned to the levels "landscapes," "regimes," and "niches":

Landscapes encompass given factors like demographic trends, political ideologies, social values, macro-economic patterns, and other factors, which have to be assumed to be more or less fixed from the perspective of the system (Fig. 1). In principle, a landscape changes slowly and is generally independent from the considered system.

Regimes reflect the interactions of science, technology, politics, markets, user preferences, rules and institutions. Despite the dynamics within a regime resulting from learning effects and other kinds of ongoing incremental changes, usually regimes display a high degree of stability.

The systems where radical innovations emerge are called niches. These niches are exclusive and protected areas without being exposed to selection pressure from markets [33] or institutionalized evaluation (e.g., security, environmental, or ethical standards). According to Geels [5], niches are characterized by expectations or visions, the building of social networks, and great learning and articulation processes. With respect to stability, clear trajectories and the public supporting structure, three different stages of niche-development can be identified: Niches with a high degree of instability and without significant lobby groups or user associations (Fig. 1, (1)), niches that are characterized by novel technological trajectories with preliminary lobbying activities (Fig. 1, (2)) and niches with new technology supported by powerful groups and which present a potential threat to existing technologies used in the regime (Fig. 1, (3)).

Momentums within the regimes as well as shocks and other kind of stresses on the landscape level can affect the regime by creating windows of opportunities or windows of threats for innovation processes (see, e.g., [34]). Depending on the main features relating to the changes of the regime, the following classification of the transition paths are used (in line with, e.g., $[5,33])$ :

- Transformation: The regime changes without recourse to one dominant technology.

- Technological substitution: The dominant technology is replaced by new radical technologies. ${ }^{3}$

- De-alignment and re-alignment: Great problems evolve in the regime, multiple niche innovations emerge, the innovation or combination of innovations which suits best comes to dominate the regime. 


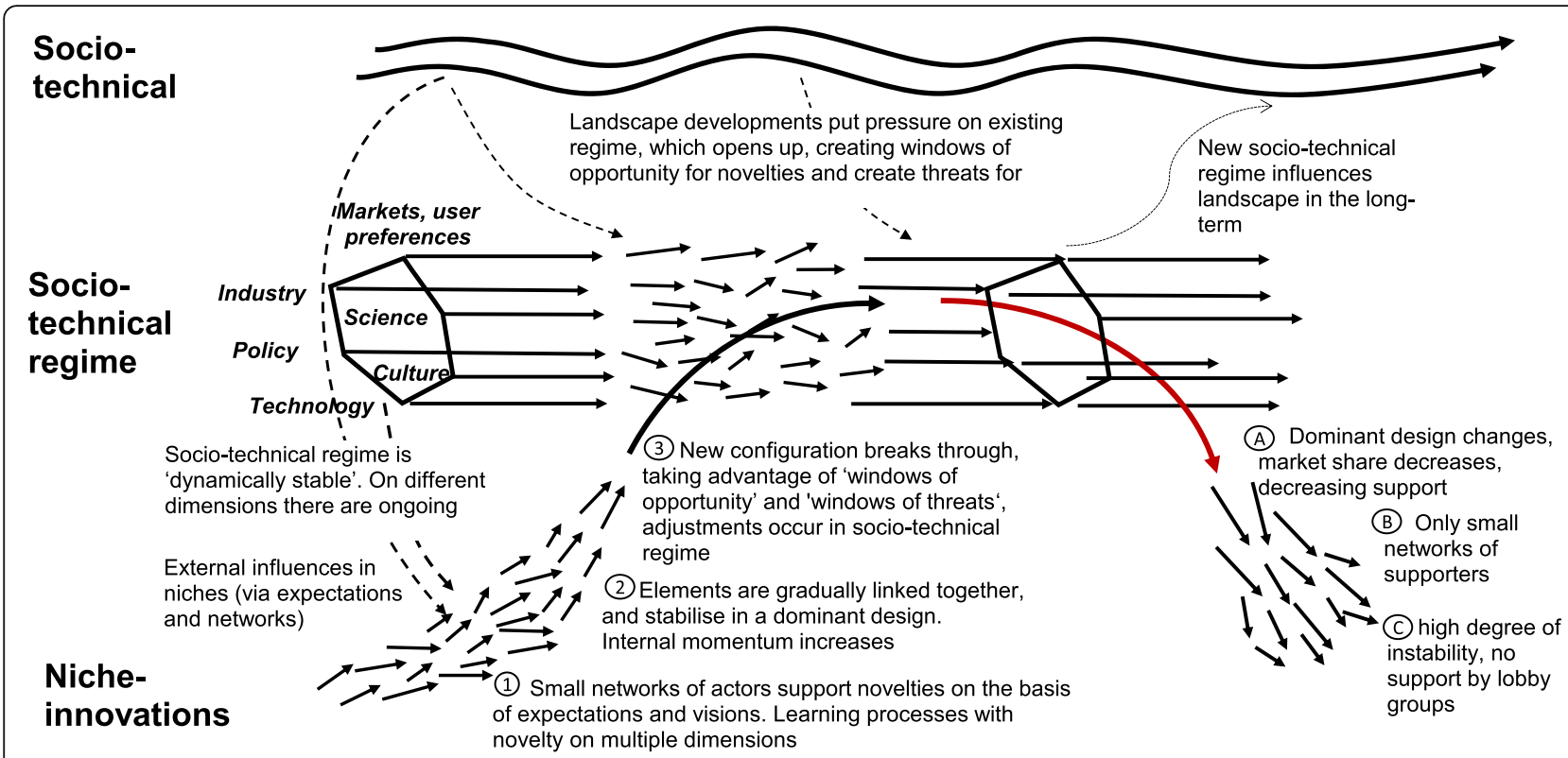

Fig. 1 Multi-level perspective on innovation processes; source, own compilation based on [33]

- Reconfiguration: The regime does not only change in terms of the used technologies but also in terms of organizational structures.

All of these different kinds of changes in the regime may affect the position of the predominant technology in the regime. The probability for remaining in the regime will increase if the technology has great unexploited improvement potential, and if the pressure of the regime as well as the pressure resulting from the changes in niches, are strong enough for unlocking this potential. Beside external pressure on an existing regime, the so-called "lock-in" effect [35] or "field logics" [36] determine the strength of the regime to find solutions to face the pressure. Industries, for example, respond to pressures on the regime with modifications in their economic and innovation strategies as well as in strategies focusing on socio-cultural and political frameworks (see, e.g., $[4,35,37,38])$. In the case of possible disruptions in economic activities of industries, the corresponding industries might get public support (see, e.g., [39]) for avoiding destruction effects in parts of the regime. Using the electricity generation sector in the UK as an example, Geels concludes that "incumbent regime actors in the United Kingdom have used instrumental, discursive material and institutional forms of power to resist climate change-related pressures and to reposition themselves for low-carbon futures without fundamental system change" ([40]:35). The stability of a regime constrains the possibilities for greater changes (see, e.g., [36, 41]). With respect to a transition of a regime (e.g., of an energy system which is based on fossil fuels towards a system that is based on renewables), measures focusing on destabilization of the old regime can support the transition process significantly and should be selected in addition to innovation policies [40, 42]. According to [43], regimes with a great heterogeneity between firms could be destabilized more easily than regimes which consist of firms showing only small differences with respect to technological prerequisites and characteristics.

Changes in an incumbent technology of a regime as well as in the regime itself could be initiated by developments in the niches even if no new technologies enter the market. As an example, the development in the car sector can be used. As Mom [44] pointed out expectations that electric vehicles could become a dominant technology, fostered $R \& D$ on combustion engines significantly and resulted in a technological leap (see, e.g., [44, 45]).

The phase-out of a technology could be prevented if there are factors (e.g., on the political level) in the regime that dominate the ones pushing aside the technology. Especially elements of the regime that belong to a strategic sector (e.g., aerospace or military) might be preserved by tight-knit sociotechnical configurations, shared institutions, and enacted by actors with vested interests (see, e.g., [46]). Beside long investment cycles, path dependencies in politics often are responsible for a technology's continued existence in the regime without great changes. Yet, especially due to an intensification of R\&D activities, some technological improvement can result. Thus, the technology has a new design, but still remains in the regime.

In case of a regime change and the coming up of new ideas, structures, and technologies, previous technologies will not stop operating immediately. Our study 
explores what happens with technologies that are on the list for being replaced. We assume that replaced technologies will be pushed back in a sub-system that is similar to the specification of niches with respect to particular expectations and esteem, a new user base, and adaptation processes. As mentioned above, three different stages of niche development can be identified. The phase-out process of a technology can be described by reversing the order of these stages: At the first stage, the technology is still supported by powerful groups but loses its importance on the market increasingly. In addition, there are growing efforts to change the technology's design. Like the second stage for technologies in niches, the second stage of the phase-out process is characterized by small networks of supporters. At the third stage, there is a high degree of instability. Significant lobby groups or user associations, which would support the technology, do not exit (see Fig. 1).
There are several possible development paths for a technology that is removed from the regime and into the sub-system mentioned above (Fig. 2, c-e):

(1) Firstly, if there are proponents who support the technology, the technology could continue to exist even within a small nutshell. Whereas for the new regime, it is not relevant that single actors continue using the technology.

(2) Secondly, the technology will take a role in a different field of application than before, with or without changing its shape (e.g., by merging with other technologies (see, e.g., [45]). The predominant technology is still used, but not in the same way as before. It can be modified in its design or meaning.

(3) Thirdly, the technology may plainly disappear. In this case, there are no supporters in politics, society, and industry anymore because a new technology is entirely beneficial. Using this categorization of possible paths for

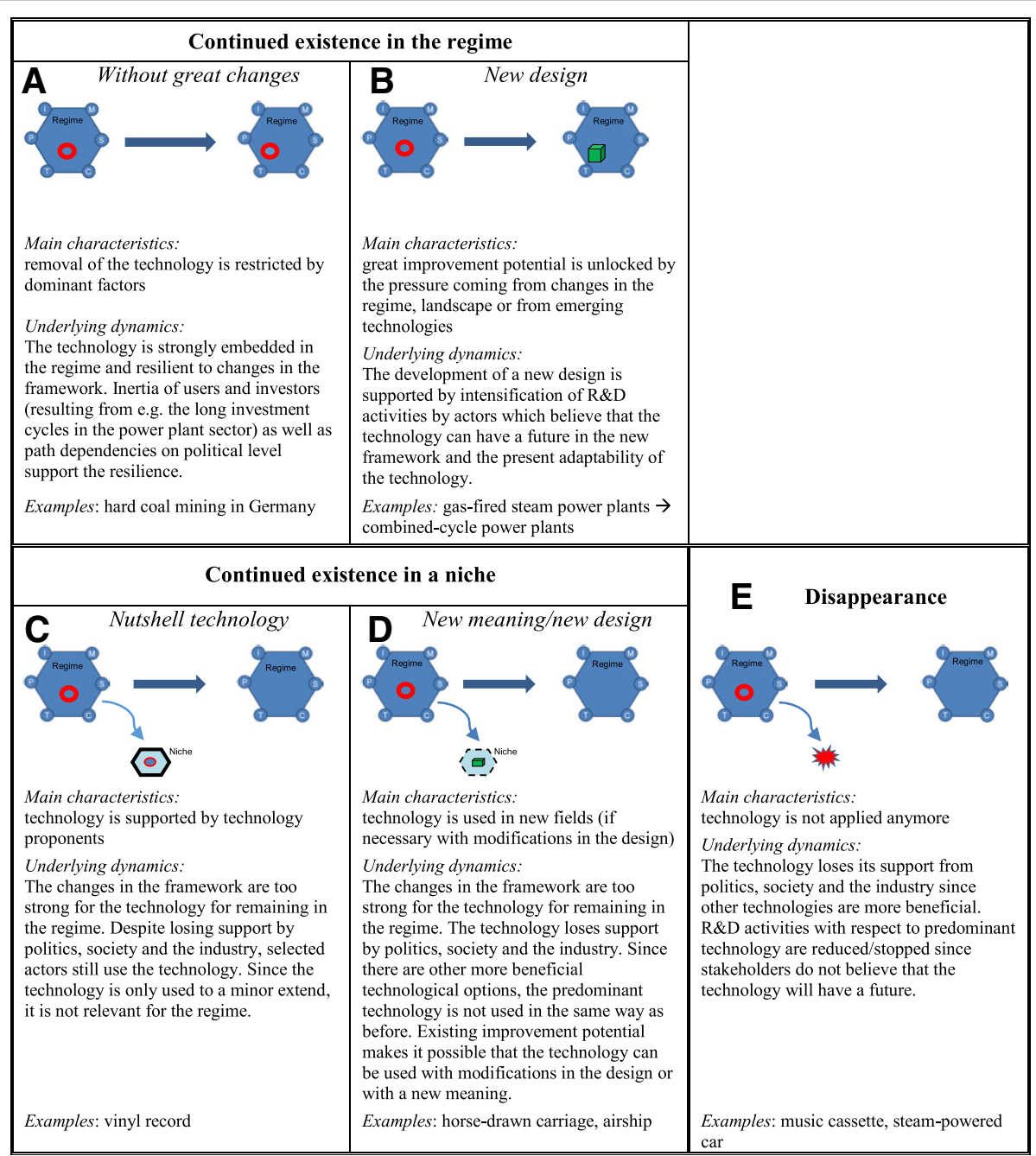

Fig. 2 Implications of changes in regime on predominant technologies; source, own compilation 
predominant technologies, we will analyze possible pathways for coal-fired plants in Germany.

Of course, in reality, innovation processes are very complex and often overlapping (see, e.g., [47]). Therefore, the classifications of processes as well as the MLP approach itself are vulnerable to some degree of fuzziness.

\section{Methods}

In the following, we employ the MLP approach to analyze possible transition pathways for the sector of coal-fired power plants in Germany. For an assessment of future pathways for coal-fired power plants, it is important to understand how these power plants got their position in the electricity system and why/how their resilience with respect to modifications of the landscape and regime has changed.

Employing the MLP approach, it is possible to structure and link factors which influence the development of the power plant sector by taking aspects beyond economic and technological spheres into consideration. For drawing conclusions on resilience of the power system, we incorporate the development of coal-fired power plants in the past. Since stakeholders which were involved in, e.g., decisions on the prioritization of political targets or on investment cannot (or only in a very restricted way) be consulted, our study relies on literature research.

Beside publications provided by ministries (e.g., German Federal Ministry for Economic Affairs and Energy [4850], Federal Ministry for the Environment, Nature Conservation and Nuclear Safety [51-53]), European Commission [54, 55], industry associations [25, 56], NGOs [57], newspapers, and press statements (e.g., statements of unions [58]), we use secondary literature. The literature review is complemented by data mining. Among the databases or datasets used for retrieving information for the power plant sector are, e.g., the power plant database of the Federal Network Agency [24] and the data collection of the Federal Ministry for Economic Affairs and Energy [22].

The information extracted from the different sources is structured and analyzed based on the MLP concept presented in the chapter "Theoretical background."

\section{Results and discussion}

By using a MLP approach, it is possible to analyze changes in a national techno-social system in a systematic way taking the interactions between the socio-economic framework and the technological developments into consideration. Since the ongoing processes in the power plant sector in Germany cannot be seen as a pure technological substitution process, we select the MLP for analyzing the process of pushing back coal-fired power plants into a niche area in Germany.
Presently, coal-fired power plants play a key role in the German energy system, despite the fact that environmental concerns about the coal sector prevail already for a long time (see, e.g., [30]). With an annual electricity production of $273 \mathrm{TWh}$, coal-fired power plants provide almost $46 \%$ of the electricity that is consumed in Germany [22]. Because of the high level of availability, the coal-fired plants are extensively used for supplying the baseload demand for electricity. They play a crucial role in balancing fluctuations in the electricity production of renewables. Politico-economic considerations are--at least regionally--also of high importance in the coal sector due to approximately 35,000 people employed in this sector (incl. coal mining and the power stations themselves) [25]. At the same time, coal-fired power plants are a big perpetrator of global warming due to greenhouse gas (GHG) emissions. In Germany, these power plants emit 255 million tons of $\mathrm{CO}_{2}$ each year which corresponds to $36 \%$ of the overall greenhouse gas emissions of the country [22, 59]. Taking into account the high importance of coal-fired power plants concerning GHG emissions, the current energy system, and local employment issues, there is a strong need for detailed analysis of possible phase-out pathways.

\section{Establishment of a regime with coal-fired power plants as key technology}

Over a very long period of time, the use of indigenous hard coal was supported in Germany by the government by granting coal-fired power station tax advantages or subsidies. ${ }^{4}$ Since the extraction of lignite was far more cost-effective than that of hard coal, the support for the two differed. Power stations for both kinds of coal benefited from restrictions on the building of oil and natural gas power stations. The first support schemes for hard coal-fired power plants were introduced already in the 1960s. In particular, decreases in the number of employees in the mining sector (1960: 640.000, 1970: 375.000 ) and the oil crises in the 1970s motivated the German government (headed by the Social Democratic Party) to expand the support for the use of hard coal in power plants. An example of this is the "coal penny" ("Kohlepfennig") introduced as compensation for additional costs resulting from using domestic instead of imported hard coal. Power plant owners and coal producers were committed to a "contract of the century" which contained large subsidy programs for the development of long-distance heat supply systems as well as the building of coal-fired CHP power plants (see, e.g., [60, 61]). The support for lignite-fired power plants focused on exemptions of lignite extraction from royalties payable for extraction of resources and from water withdrawal charges [52]. 
In addition, energy research programs were implemented by the government for supporting the development of new coal power plant technologies with up to 270 million euro (2014 prices) per year [62]. The high share of coal on the overall spending on $R \& D$ (up to 60\%) for non-nuclear energy technologies highlights the great importance of coal in the German energy policy between 1970 and 1990. In this period, the electricity market was split into regional monopolies with RWE, PreussenElektra AG, Vereinigte Elektrizitätswerke Westfalen (VEW), Bayernwerk, Badenwerk AG, Energie-Versorgung Schwaben AG (EVS), Bewag Aktiengesellschaft, and Hamburgische Electricitäts-Werke AG (HEW) as main players. Regulations on investment control and price supervision set in the Energy Industry Act (Energiewirtschaftsgesetz) aimed to limit market abuse of the monopolists. However, the investment control limited the possibilities for new players to enter the market.

The coal-fired power plants dominated the electricity production whereas coal technologies mainly faced competition from nuclear power plants [22]. The relatively high demand for new coal power plants provided sufficient room for a large number of companies supplying components for power plants.

All in all, coal-fired power plants were well integrated into the regime and were supported by most of elements of the regime: From the government's viewpoint coal-fired power plants helped to increase energy security (incl. less dependency on fossil fuels from oil exporting countries) and decrease losses of jobs in the coal mining and coal-fired power plant sector. The utilities benefit from a calculable cost for investments and society from employment effects. With the increasing use of coal- and oil-fired power plants, a lot of environmental problems emerged, namely smog and acid rain (see, e.g., [63]). In reaction to environmental concerns, the Ordinance on Large Combustion Plants with emission limits for $\mathrm{SO}_{2}, \mathrm{NO}_{\mathrm{x}}$, and dust was enacted at the beginning of the 1980s. Because of long transitional periods and the potential for the sector to pass on additional costs, the regulations did not affect the power plant sector significantly.

\section{Coal-oriented regime and lock-in effects}

Additionally, there exist lock-in effects which work against a phase-out of coal-fired power plants and keep the technology in the system regime. One of them is the activities of lobbyists and interest groups in the coal sector (e.g., IG Bergbau, Chemie, Energie; Deutscher Braunkohlen-Industrie-Verein; Bundesverband der Energie-und Wasserwirtschaft) (see, e.g., [64]). Beside information and public relation activities, they also try to actively influence the legislative procedure. Their three main arguments for a continued support of the coal sector are high costs of renewables, a threatened energy security, and job losses [65]. Furthermore, many politicians are involved in the coal industry. The environmental association "Greenpeace" published the so-called "Schwarzbuch Kohlepolitik" [66] where 45 German politicians of almost all parties who are supporters of the coal industry are portrayed.

The following example highlights the linkage between politics and the coal sector. Recently, the EU commission decided with a $65 \%$ majority that emissions including $\mathrm{SO}_{2}, \mathrm{NO}_{2}$, and dust should not exceed the emission levels associated with the Best Available Techniques (BAT) as described in the "BAT reference document for Large Combustion Plants (LCP BREF)" ([67]:6). Thus, the emission limits for German coal-fired plants (with power exceeding $300 \mathrm{MW}$ ) have to be reduced significantly. By 2021, the new resolution has to be implemented into the national regulations of the European countries [67]. Germany voted against the proposal. Especially, the German lignite industry was concerned about the required stricter emission limits. Because of a lack of technological feasibility [68], the German government favors a higher limit for $\mathrm{SO}_{2}$ emissions than is required by the EU [69].

A further lock-in effect becomes apparent in the following fact: the 130 German municipalities, administration unions, and municipal enterprises are shareholders of around 24\% of RWE (the second largest utility in Germany) [70]. A phase-out of coal-fired power plants would imply significant losses in the budget of municipalities. There are also highly localized historical reasons for sticking to an old technology, in particular coal mining which is often seen in melancholic terms, and acts as a further lock-in effect [71].

\section{Disturbances of the regime}

The situation for coal-fired power plants began to change in the 1990s. At the beginning of this decade, the "Electricity Feed-In Act" was enacted aiming to increase the use of renewables for electricity generation. In 1995, the coal penny was declared to be unconstitutional. A renewed amendment of the electricity generation law and new regulations for compensations resulted (see, e.g., $[60,72])$. In consequence, the volume of electricity generated from domestic hard coal gradually decreased. The liberalization of the electricity market (forced by activities on the European level) and the repeal of the quasi-prohibition ${ }^{5}$ of the construction of gas- and oil-fired power stations at the end of the 1990s represented another drastic break for the coal power industry. The immediate liberalization of the monopolized electricity market meant that many enterprises were exposed to enormous pressure to decrease their costs, which led to extensive cost-saving measures. Despite the demand 
for upgrading power plants in East Germany, the power plant construction sector was confronted with a decreasing market (see Fig. 3).

As a result of the shrinking market, a lot of power plant manufacturers merged. Increasing cost pressure and intentions to secure their position in the new market resulted in companies merging in the electricity sector as well (see, e.g., [73]).

The greatest changes in Germany happened in the last 10 years: Variations in the structure of electricity production are the results of fundamental changes in the framework conditions. Beside (1) impulses from changes on the market for fossil fuels, (2) environmental and energy policies on the international as well as European level, (3) changes in political targets on the national level, (4) R\&D activities, and (5) developments on industrial and society levels have impacted the transformation of the electricity system (see, e.g., [23, 30, 74]). Figure 4 shows events on the landscape level (e.g., oil crises, nuclear accidents) which are usually mentioned as examples for events with significant impact on the German energy system and as key characteristics of the modified regime (see, e.g., [30]). Modifications in the regime comprise changes on the governmental level (e.g., introduction of new laws in reaction to shocks on the global level or decisions on the European level) as well as adjustments of the industries' activities to changes in prices and laws as well as in public perceptions (e.g., with respect to nuclear energy).

Although the regime was confronted with greater challenges, with a technological availability of more than $90 \%$ and with a comparable high flexibility, coal-fired power plants still remained as an important pillar in the electricity supply system. This manifests in a contribution of $37 \%$ on the overall electricity production [22]. Due to feed-in tariffs, different kinds of R\&D subsidies, and increasing support by the industry and the public, the market for wind and PV technologies rose significantly (see, e.g., [75]). However, wind and PV did not represent a significant threat for the conventional power plants (in particular since gas-fired plants determined the wholesale price).

In addition to ongoing merging processes, the decade from 2000 to 2010 was shaped by the introduction of the Renewable Energy Sources Act (EEG) and its amendments, the "Act on the structured phase-out of nuclear power for the commercial production of electricity" (2002) enacted by the federal government, along with the implementation of emissions trading in Germany (2004), the agreement on the termination of hard coal extraction in a socially acceptable manner by the end of 2018 [76] combined with a strong decrease in the state assistances for coal (see Fig. 5).

Also the energy concept with targets like increases in the share of final energy consumption from renewable energy sources (from approximately $10 \%$ in 2010 to $60 \%$ by 2050) and an increase in the share of electricity generated from renewable energy sources (from approximately $17 \%$ in 2010 to at least $80 \%$ by 2050) was a far-reaching occasion for rethinking the role of coal-fired power plants [51, 77]. With increasing use of renewable instead of gas-fired power plants, coal-fired power plants set the price at the wholesale market. Accordantly, it becomes more and more difficult to run coal-fired power plants profitably. Since 2008 at selected points in time, the wholesale prices even have become negative because of low demand and strong wind power outputs. More and more the big utilities realized that despite providing power plant capacity for backup reasons in future, it would be very difficult to make profits (like in the past) with coal-fired power plants due to decreasing prices at the whole market (resulting from extended use of renewables) and increasing actors on the electricity balancing market offering capacity at low cost.

Furthermore, the decrease in the willingness to build fossil-fired power plants was supported by (1) uncertainties

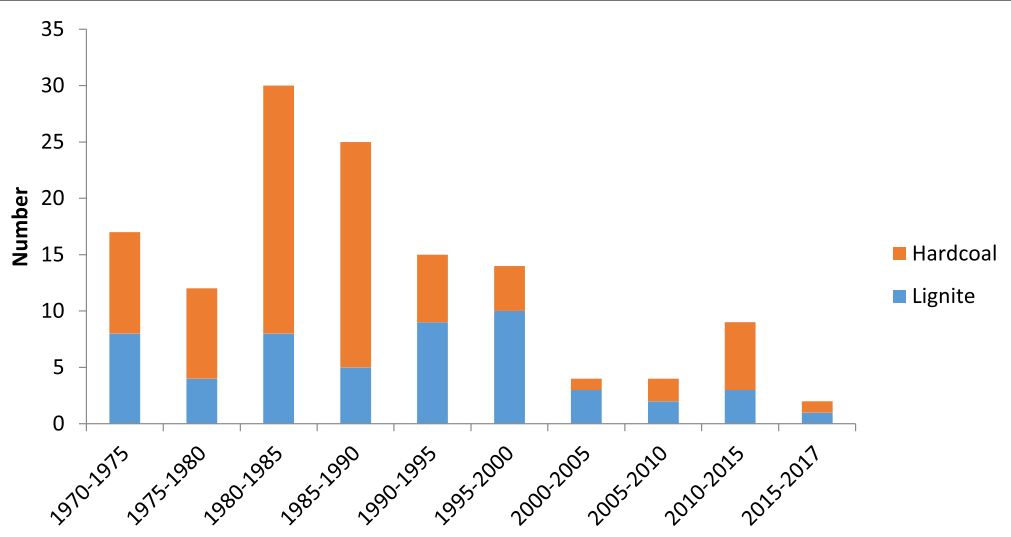

Fig. 3 Number of coal power plants built per period, source [24] 


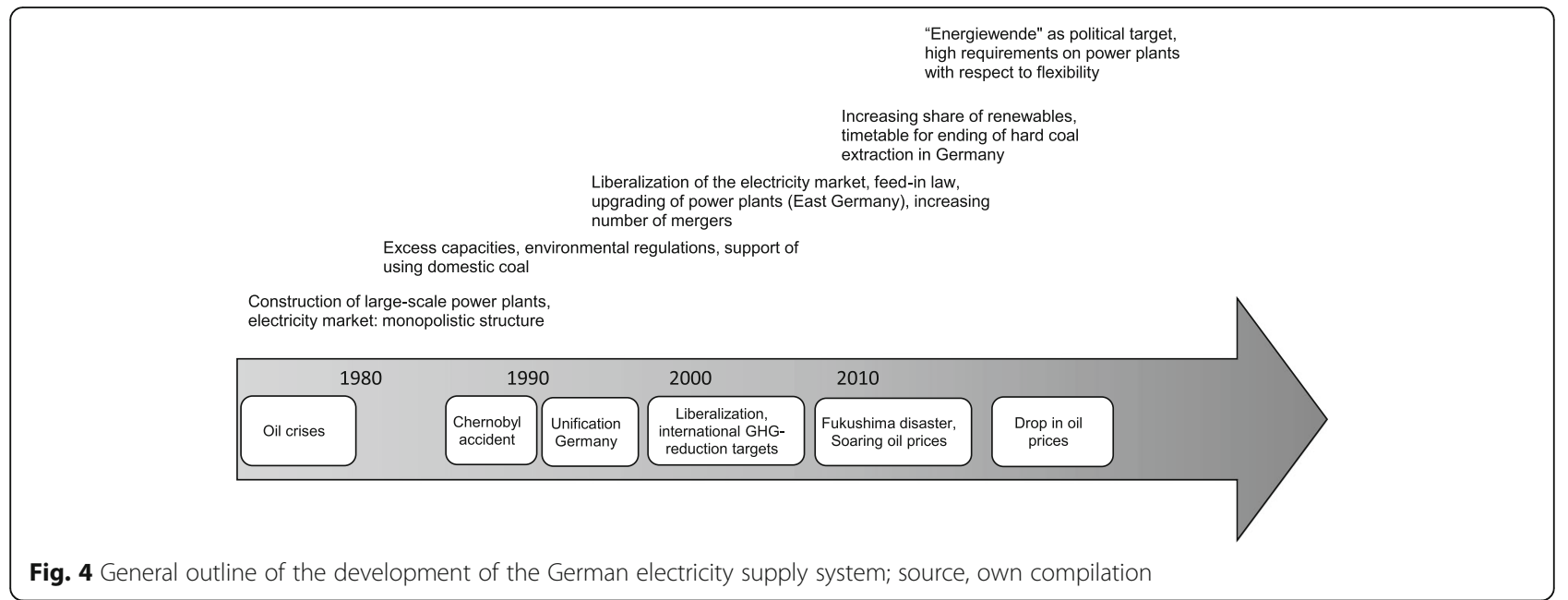

about the refinancing of coal-fired power plants resulting from concerns about running costs in the electricity markets, (2) cost increases caused by the emission trading scheme, and (3) lower prices for electricity on the wholesale market resulting from an increasing share of renewables in the regime (see, e.g., [56, 78]).

This uncertainty largely originates from rising public criticism on the building of new coal-fired power plants. Due to very low $\mathrm{CO}_{2}$ prices and comparable high-fuel prices, the running costs of coal-fired power plants are still lower than the ones of gas-fired plants. Thus, the utilities are interested in using their existing coal-fired plants for as long as possible. Despite a high increase in $R \& D$ expenditures for renewables, the public $R \& D$ expenditures for fossil power plants had been still on a relatively high level [62]. The big utilities as well as many other stakeholders had the hope, that if the efficiency of coal-fired plants increased, $\mathrm{CO}_{2}$-reduction targets would not affect their use dramatically in the mid-term [50].

\section{Destabilization of the role of coal-fired plants in the regime}

Usually, the Fukushima disaster in the year 2011 is mentioned as the turning point for German energy policy (see, e.g., [79]) and [74]). However, the starting point of restructuring the German energy system towards a low-carbon one was set in the years before by implementing the "German Energy Concept" (see, e.g., [64]). Additionally, the disaster changed the attitude of the German government with respect to the use of nuclear energy $[31,80]$. The energy package which was released in 2011 includes new laws like the Nuclear Energy Act with a warm-down of German nuclear power plants until 2022; the Act to Restructure the Legal Framework for the Promotion of Electricity Generation from Renewable Energy and the Act on Measures to Accelerate the Expansion of the Electricity Grid (NABEG). On a political as well as utility level, there was the hope that by using carbon capture and storage (CCS) technology, coal power plants could still play an important role in the

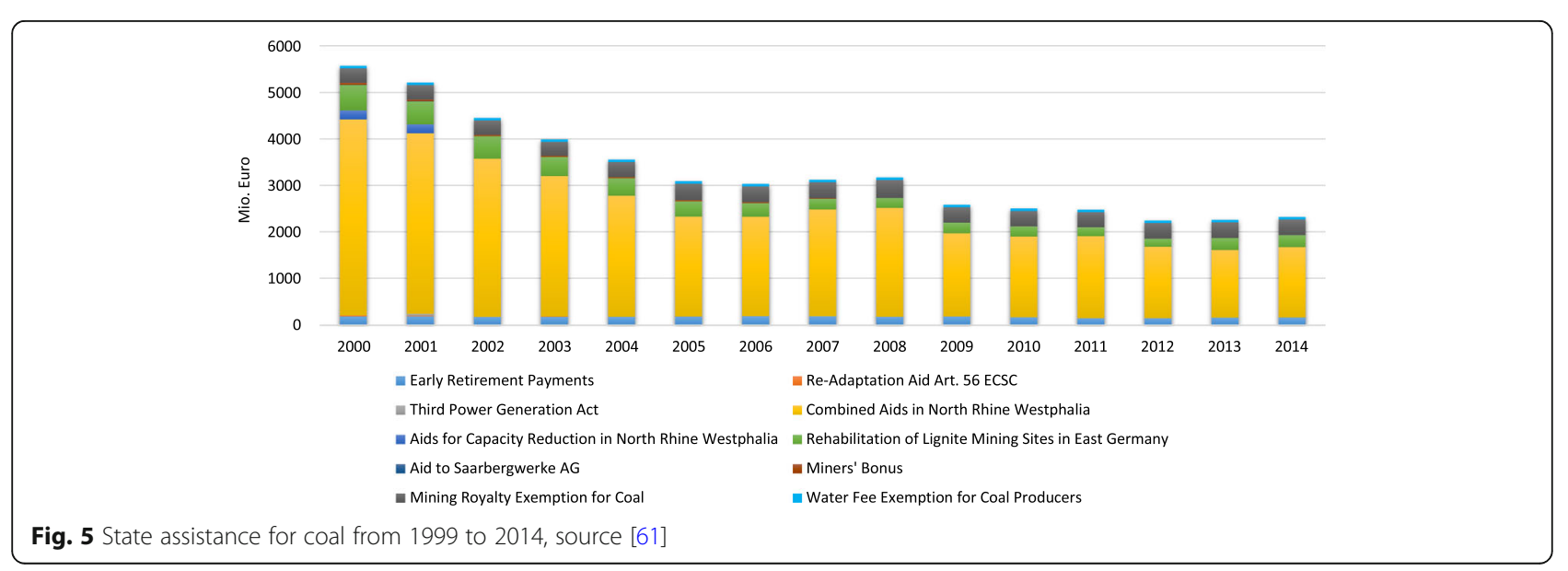


energy system [48]. Decisions on the EU level with respect to CCS and the enforcement of the CCS Act (2012) supported these expectations. However, due to the unforeseeable costs of CCS power plants as well as problems in the public acceptance linked to storage and transport of $\mathrm{CO}_{2}$ and limited storage potential, CCS lost many of its supporters in Germany (and in other countries in Europe) (see, e.g., [79, 81]).

In 2012, an amendment to the Energy Act was enacted which includes restrictions on power plants greater than $10 \mathrm{MW}$. These power plants cannot be shut down without informing the responsible transmission operator and the Bundesnetzagentur. If one of these power plants is declared as system relevant, its shutdown will be prohibited. In this case, the power plant is not allowed to participate in the wholesale market. Beside gas-fired plants, the "ban on plant closure" also impacts coal-fired power stations. Against the backdrop that Germany will miss its GHG reduction target of $40 \%$ (compared to 1990) by 2020 (Fig. 6), additional measures had been specified by the government. The electricity sector was identified as a sector that should contribute greatly to a further reduction of GHG emissions (Table 1). In this context regulations like a "climate levy" for coal power plants have been discussed.

In 2015, the German government and the energy companies RWE, Vattenfall and Mibrag agreed to put lignite-fired power plant capacities on standby (see Table 2). As compensation for mothballing their power plants, the utilities get 230 million euro per year for the 7 years. ${ }^{6}$

For example, with the updated LCP BREF also the EU put increasing pressure on their member states. Moreover, it seems that even interest groups of the coal industry face up to the downfall of coal-fired energy. So, the German labor union discusses almost solely how a phase-out of coal-fired power plants and coal mines can be conducted with lowest possible impact on the labor market. They rather require a "just transition" [82] than the maintenance of the coal industry.

\section{The transition pathways towards a regime without coal- fired power plants}

All in all, the building of new coal-fired plants was canceled because of (1) limited political support, (2) increasing pressure from the growing market share of renewables coming from niches and becoming a central element of the regime, (3) major changes in the power plant construction sector due to a long period of low demand for new power plants in Germany, (4) decreasing public acceptance, and (5) being unable to make a great contribution for reaching the GHG reduction targets. Cost advantages of coal-fired power plants in comparison to gas-fired ones and the advanced age of the existing power plant stock are the main reasons behind the willingness of utilities for putting new coal-fired power plant into operation.

Since gas-fired plants determined the wholesale price, renewables did not threaten coal production. With increasing use of renewable instead of gas-fired power plants, coal-fired power plants set the price at the wholesale market. Therefore, it becomes more and more difficult to run coal-fired power plants profitably. Since 2008 at selected points in time prices even became negative because of low demand and strong wind power outputs. More and more, the big utilities realized that despite providing power plant capacity for backup reasons, in future, it would be very difficult to make profits (like in the past) with coal-fired power plants due to decreasing prices at the wholesale market (resulting from extended use of renewables) and increasing actors on the electricity balancing market offering capacity at low cost (see Fig. 7 for comparison of whole prices and cost for coal-fired power plants).

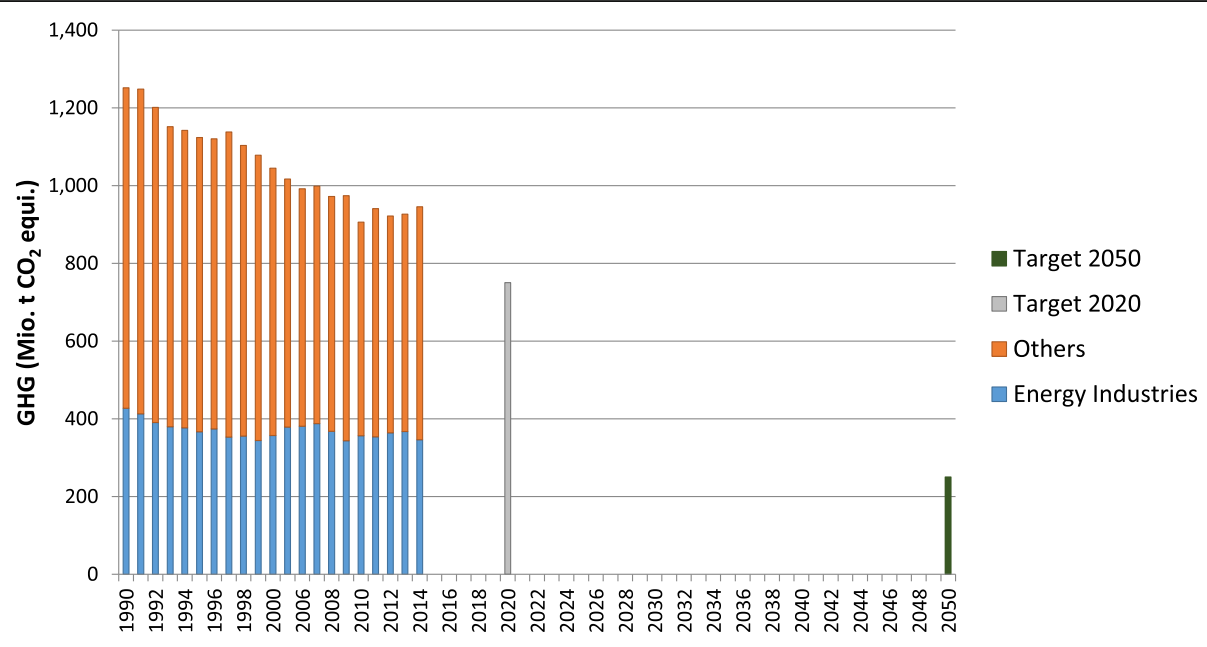

Fig. 6 GHG Emissions and targets, source [59] 
Table 1 Climate action program 2020

\begin{tabular}{|c|c|}
\hline Key policy measures & $\begin{array}{l}\text { Contribution to greenhouse } \\
\text { gas emission reduction (million } \\
\mathrm{t} \mathrm{CO}_{2} \text { equivalent) }\end{array}$ \\
\hline $\begin{array}{l}\text { National Energy Efficiency Action Plan } \\
\text { (NAPE) (without measures in the } \\
\text { transport sector) }\end{array}$ & $\begin{array}{l}\text { Approx. } 25-30 \text { million t } \\
\text { (including energy efficiency } \\
\text { in buildings) }\end{array}$ \\
\hline $\begin{array}{l}\text { Strategy on climate-friendly building } \\
\text { and housing (contains NAPE measures } \\
\text { specific to buildings) }\end{array}$ & $\begin{array}{l}\text { In total approx. } 5.7-10 \\
\text { million } t \\
(1.5-4.7 \text { million } t \text { of which } \\
\text { in addition to NAPE }\end{array}$ \\
\hline Measures in the transport sector & Approx. 7-10 million t \\
\hline \multicolumn{2}{|l|}{$\begin{array}{l}\text { Reduction in non-energy-related } \\
\text { emissions in the sectors: }\end{array}$} \\
\hline $\begin{array}{l}\text { Industry, commerce/trade/services, } \\
\text { and waste management }\end{array}$ & 3-7.7 million t \\
\hline Agriculture & 3.6 million $t$ \\
\hline Emissions trading reform & $\begin{array}{l}\text { Dependent on decisions } \\
\text { at EU level }\end{array}$ \\
\hline $\begin{array}{l}\text { Further measures, especially in the } \\
\text { electricity sector }\end{array}$ & 22 million $t$ \\
\hline Total & 62-78 million t \\
\hline
\end{tabular}

Source: [56]

Thus, RWE and EON decided to separate the conventional power generation business from their core business by forming new subsidiaries. Vattenfall Germany sold their lignite-fired power plants and the mines in Eastern Germany. A further milestone was set on the 5th of April 2017 when the European association of the energy sector "Eurelectric," which represents 3500 European utilities, pledged to no longer invest in coal-fired power plants after 2020. Hence, the members of the association, 26 out of the $28 \mathrm{EU}$ countries (except Poland and Greece), committed themselves to the phase-out of coal-fired power plants [83].

It is largely assumed that due to dynamic restructuring processes, the sector will continue to exist in the next decades (Fig. 8). Long payback periods, high-specific investment cost, and the importance of GHG reduction measures (as well as for other kinds of environmental policies) are some of the main characteristics of the sector.

Taking into account the fact that coal is losing its support from utilities and the public, as well as political support, and that no greater efficiency improvement potential for coal-fired power technologies is seen, ${ }^{7}$ it can be expected that in future, coal power plants will only be used in niches or disappear completely (Table 3 ). Currently, it is very unlikely that stakeholders will still favor the technology despite the concerns about coal-fired power with respect to environmental harms and for economic reasons (Table 3, section A).

Because of limited improvement potential and the loss of support for CCS technology, a continued existence of coal-fired power stations in a new design is not a plausible option in the long run (Table 3 , section $\mathrm{B}$ ).

Instead of this continued existence in the regime, coal-fired power plants will become a niche technology or will disappear completely. Referring to the MLP approach, we describe the transformation of a technology existing originally in the regime, being pushed back into becoming a niche technology. Coal-fired plants may continue to exist as Nutshell technology (Table 3, section C). Some of the coal-fired power plants might be used for electricity production with regard to socially responsible layoff schemes and by meeting requests of the owners of the power plants. In this case, social aspects dominate environmental concerns. Another reason for their further use is a possible need for a local energy supply system. For a use as a nutshell technology, an agreement on the remaining lifetime of the power plants is needed. Such a development will be possible if opponents against coal-fired power plants have come off second best and the use of a low number of coal-fired power plants is seen as acceptable for the public. Since the German government still aims to reach environmental goals and there are powerful pressure groups which want to phase-out coal-fired power plants, it is, under

Table 2 Date of mothballing and decommissioning of lignite-fired power plant units

\begin{tabular}{lllll}
\hline Operator & Unit & Capacity (MW) & Date of mothballing & Date of decommissioning \\
\hline Mibrag & Buschhaus & 352 & October 1, 2016 & September 30, 2020 \\
RWE & Frimmersdorf P & 284 & October 1, 2017 & September 30, 2021 \\
& Frimmersdorf Q & 278 & October 1, 2017 & September 30, 2021 \\
& Niederaußem E & 295 & October 1, 2018 & September 30, 2022 \\
& Niederaußem F & 299 & October 1, 2018 & September 30, 2022 \\
& Neurath C & 292 & October 1, 2019 & September 30, 2023 \\
Vattenfall & Jänschwalde F & 465 & October 1, 2018 & September 30, 2022 \\
& Jänschwalde E & 465 & October 1, 2019 & September 30, 2023 \\
Total & & &
\end{tabular}

Source: [58] 


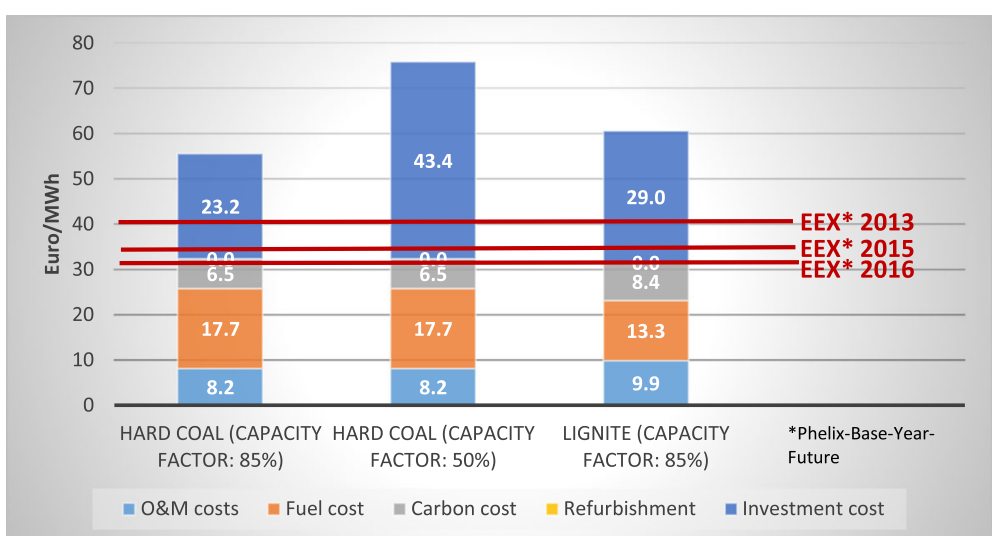

Fig. 7 Electricity generation cost and prices on the wholesale market, source [56, 78]. Remarks: EEX 20xx, average price for baseload at the spot market at the corresponding year; assumptions, internal rate of return 10\%, $10 \$ / \mathrm{t} \mathrm{CO}$; efficiency for hard coal-fired power plant, 46\%; lignite-fired power plants, 43\%; price for hard coal $75 \$ / t$

recent circumstances, very unlikely that coal-fired power plants will be in use after 2040.

In principle, it is also possible that coal-fired power plants continue to exist but with a new meaning (Table 3, section D). In this case, most of the coal-fired power plants that are not decommissioned will be used as backup power plants providing capacity instead of electricity. Since the power plant owners would not get revenues from selling electricity, compensation schemes would have to be implemented. This could be done by paying money to power plant owners individually (as is done currently) or by introducing a capacity market. The European Commission might well consider payments to be inadmissible subsidies. Hence, a direct support of power plant operators would be difficult. The introduction of a capacity market seems to be easier. However, a restriction on specific emissions like the $550 \mathrm{~g} \mathrm{CO}_{2} / \mathrm{kWh}$ limit which is currently under discussion on the European level [84] would prevent coal-fired plants from taking part in a capacity market. Even if direct payments or participation on a capacity market were possible, because of acceptance problems and financial risks, a construction of new coal-fired power plants will be out of question. As the requirements (e.g., short ramp-up times) for power plants used as backup capacity are different to those of stations providing baseload electricity, the existing power plants would have to be upgraded.

Eventually, coal-fired plans will likely disappear completely (E). In the long term, it is probable that the use of coal becomes superfluous because some new technology will be more beneficial on all fronts. The public spending on coal-fired power plants would be cut. There would be no supporters in politics, society, and industry anymore. A fast phase-out will become more likely if the Green Party enters government again. The Social Democratic Party (SPD) and Christian Democratic Union (CDU)/Christian Social Union (CSU), which form the current government favor a gradual withdrawal of coal-fired power plants without questioning the phase-out process of coal-fired power plants. In their coalition agreement, they highlighted their intention to reach the $40 \%$ GHG reduction target, to

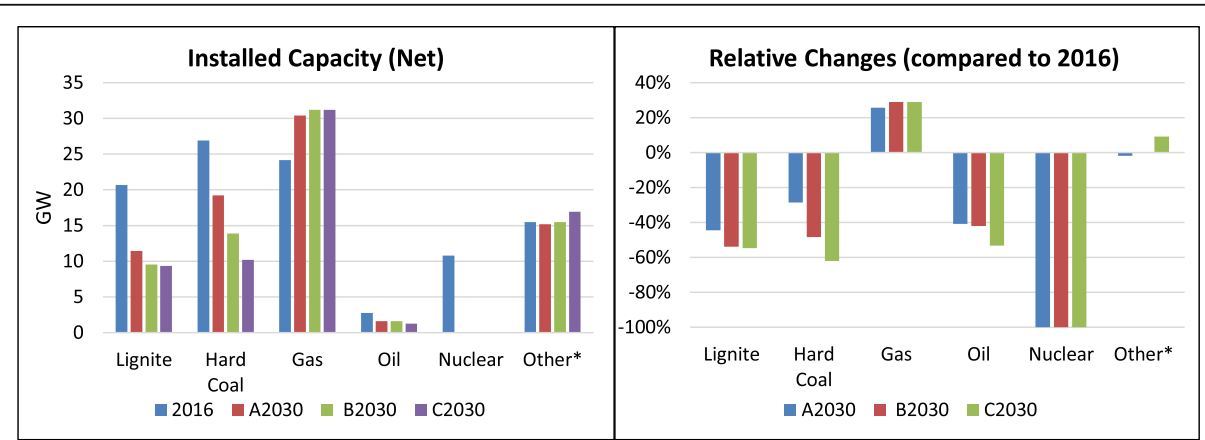

Fig. 8 Expected changes in installed capacity, source: [105]. Remarks: *without renewables. The scenarios A2030, B2030, and C2030 differ with respect to the assumed speed of the transition process of the Germany energy system. A2030, moderate; B2030, accelerated; C2030, rapid implementation 
Table 3 Possible futures for coal-fired power plants

\begin{tabular}{|c|c|c|c|}
\hline \multirow[t]{2}{*}{ Category } & \multirow[t]{2}{*}{ Impacts/challenges (e.g., for politics) } & \multicolumn{2}{|c|}{ Option for "coal-fired power plants"? } \\
\hline & & & Reason \\
\hline \multicolumn{4}{|c|}{ Continued existence in the regime } \\
\hline (A) Without great changes & \multirow{2}{*}{$\begin{array}{l}\text { Market share of renewables and gas } \\
\text { technologies on electricity production } \\
\text { will increase only slowly, } \mathrm{CO}_{2} \text { emission } \\
\text { have to be stored }\end{array}$} & No & $\begin{array}{l}\text { Only limited support for coal by the public, } \\
\text { investors/politics }\end{array}$ \\
\hline (B) New design & & No & $\begin{array}{l}\text { Limited improvement potential, CCS is out } \\
\text { of discussion }\end{array}$ \\
\hline \multicolumn{4}{|l|}{ Continued existence in a niche } \\
\hline (C) Nutshell technology & $\begin{array}{l}\text { Agreement on the period selected } \\
\text { coal-fired power plant can be used is } \\
\text { needed }\end{array}$ & Yes (for a limited time) & $\begin{array}{l}\text { Specification on remaining lifetime (e.g., } \\
\text { with regard to socially responsible layoff } \\
\text { schemes) }\end{array}$ \\
\hline (D) New meaning & $\begin{array}{l}\text { supporting schemes with focus on } \\
\text { capacity are necessary }\end{array}$ & Yes & $\begin{array}{l}\text { Use of existing coal-fired power plants as } \\
\text { backup capacity }\end{array}$ \\
\hline (E) Disappearance & $\begin{array}{l}\text { Public spending on R\&D for coal-fired } \\
\text { power plant can be cut }\end{array}$ & Yes (in the long term) & $\begin{array}{l}\text { No significant incentives for investments } \\
\text { in new coal-fired power plant }\end{array}$ \\
\hline
\end{tabular}

increase the share of renewables and to establish a commission with the objective to reduce coal-fired generation. Taking into consideration that even the union parties expect that the phasing out process of coal-fired power plants is unlikely to be stopped, the long term.

Pressure on the owners of coal-fired power plants in combination with uncertain prospects for operating their power plants may trigger an agreement on their part, resulting in a "voluntary" phase-out within a few decades.

All in all, niches could provide room for maneuvering required for the transformation of power plant technology, e.g., with respect to the use of other kinds of fuels (including biofuels and solar radiation). Taking into account the ambitious $\mathrm{CO}_{2}$ reduction targets set by the German government, a renaissance of coal as a main pillar of the German energy system is very unlikely. Thus, coal-fired power plants will not present a threat for new technologies (mainly wind and PV power stations) that will come to dominate the regime.

\section{Effects}

The change of the regime will affect Germany in many different ways. Coal-fired power plants (in combination with the coal mining sector) have to be considered as one element in an evolving system that encompasses economic as well as social and environmental aspects (see, e.g., [85]). Beside effects resulting from releasing staff working in power plants and mines, there will also be indirect economic effects because of lower demand for goods and services needed for running the power plants [25]. Changes in income as well as changes in the profits of companies could impact tax revenues which could adversely affect the budget of corresponding local communities.

In Germany, currently about 25 billion euro are spent on coal R\&D annually [62]. Phasing out coal-fired power plants means public R\&D expenditures can and will decrease which will in turn affect the $R \& D$ infrastructure, including research at universities and public research institutes. Less investment in R\&D could impact the international competitiveness of power plant components' producers in Germany. This will ultimately lead to a reduction in exports of power plant components. From 2006 to 2016, public R\&D on energy efficiency increased from 24 to 183 million euros, and the R\&D for renewables from 103 to 244 million euros. Currently, 40 million euros are spent on fossil fuels. Thus, a spending cut on fossil fuels would not cause a significant damage to $R \& D$ spending. The loss in support for coal-fired power plants is an ongoing process. Currently, most political parties agree that in the long term (> 2040), coal will no longer be used for power generation in Germany. Nuclear as substitute for coal-fired power plants is out of discussion because of uncertainties regarding cost and appeals as well as unsolved security and waste problems (see, e.g., [30, 80, 86]). Regarding flexibility and storage options that support an electricity system without coal-fired and nuclear power plants, there are still a lot of open questions. However, there are a lot of $R \& D$ projects focusing on storage technologies (incl. "power-to-X" technologies).

Since a phasing out of coal-fired power plants means less coal has to be imported, this could also impact coal exporting countries like Australia, Russia, Columbia, the USA, and South Africa.

In Germany, for cooling purposes the existing thermalelectric power plants need 13 billion cubic meters of fresh water annually (which corresponds to $47 \%$ of total water demand [87]). Not only the phasing out of coal-fired power plants but also the closing of opencast pits will result in extensive changes in water management (see, e.g., [88]). In the past, coal-fired power plants were built close 
to coal mines in order to minimize transportation cost. Since new non-coal-fired power plants are not restricted by such logistical considerations, factors like proximity to consumers of electricity, as well as wind and solar conditions will influence the choice of location for new power stations significantly more. Consequently, with a phase-out of coal-fired power plants, the existing electricity grid will have to be modified. Because new power lines are usually confronted with public perception problems greater modifications of the transmission grid will likely be very time consuming (see, e.g., [89]).

With the phase-out of nuclear power plants in Germany (see, e.g., $[86,90]$ as well as with phasing out processes of nuclear in other countries (see, e.g. [91]), much experience on the different impacts of replacing a main pillar of many electricity systems has been gained. In Germany, first steps towards phasing out--or at least limiting--the use of nuclear power were taken after the nuclear accident in Chernobyl. The phase-out process of nuclear power started in times of high-excess capacity amounts and will last decades. The phase-out of coal-fired power plants is an even greater challenge as the electricity market is increasingly dominated by renewable energy with fluctuating electricity feed-in and is also linked with significant employment effects on the local level. Hence, the unions, "United Services Trade Union" (Verdi) and "Trade Union for Mining, Chemicals and Energy Industries" (IG BCE) demand a socially acceptable transformation favoring a gradual withdrawal of coal-fired power plants [58, 92].

Without a phase-out of coal-fired power plants, the national GHG reduction targets cannot be reached (see, e.g., [21]). Thus, like Denmark and Great Britain, the German government is interested in defining phase-out paths for coal-fired power plants (see, e.g., $[93,94])$. An analysis of the climate research institute "Climate Analytics" reveals that 25\% of coal-fired power plants operating in European countries need to be shut down by 2020 , rising to $72 \%$ by 2025 and reaching $100 \%$ by 2030 [95]. Only then, would the EU stick to the Paris Agreement.

\section{Conclusions}

By means of the MLP approach, we analyze possible phaseout pathways of coal-related technologies, highlighting that these processes are influenced by different factors. The set of factors includes economic, political, technical elements, and social factors. By using a MLP approach, it is possible to analyze changes in a techno-social system in a systematic way taking the interactions between the socio-economic framework and technological developments into consideration. Since the ongoing processes in the power plant sector in Germany cannot be seen as a pure technological substitution process, we select the MLP for analyzing the process of pushing coal-fired power plants into a niche area in Germany and analyzing possible landings for coal-fired power plants and their related industries. In our case study, the concept for describing processes within niches is applied for the phase-out process of coal. Until now, the concept has only been used for analyzing the emerging of new technologies. We used an approach that is slightly different to the one introduced in the standard literature on MLP because the way back into the niches is linked with experience gained with the predominant technology. This concerns in particular aspects like the design of a technology.

In the past, the regime in which the coal-fired plants are located has shown a lot of dynamics resulting from changes in economic and social frameworks as well as from change in the setting of priorities by decisionmakers. For a long time, coal-fired power plants could assert their position in the regime. Yet, against the background of decreasing public acceptance, economic problems resulting from growing use of renewable, and ambitious GHG reduction targets, the coal-fired power sector cannot resist the pressure coming from the regime anymore. Thus, the sector has been pushed onto a phasing out pathway.

In Germany, the governing parties agreed on the establishment of a commission called "Growth, structural change and employment" which is to develop a strategy for phasing out coal-fired power plants. This commission will consist of experts and stakeholders from industries, associations, unions, scientific community, pressure groups, and politicians [96]. The broad range of experts and stakeholders shows that the phasing out process has many facets and could only be assessed by using interdisciplinary approaches. The establishment of the commission shows furthermore that the phase-out process deserves close attention and policies for management, which have to be implemented for ensuring a soft landing of the electricity sector. A management of the niches where the coal-fired power will be pushed could include a protection of space for ensuring a smooth removal of the links between the regime and the technology with respect to, e.g., social and environmental aspects.

The EU encouraged carbon capture and storage as a technology for fossil fuel-based generation in the power sector (see, e.g., [54]); this technology may in principle contribute to a more stable transformation of the electricity sector in Germany. Yet, as Renn and Marshall [30] point out, "[i]nterestingly enough, carbon sequestration (CCS) has never gained much popularity in Germany" ([30]:232). Therefore, CCS is unlikely to contribute to a soft landing of the electricity sector in Germany, despite some analyses suggesting that this technology should not be excluded per se as a climate protection option (see, e.g., [97, 98]). The example of CCS illustrates the complexity of the transformation and the involved 
different aspects (economic, political etc.), as well as the need for the application of research approaches, like the MLP approach, taking into account these various relevant aspects. Phasing out coal-fired power plants is not only on the agenda in Germany but also in Great Britain and other European countries [99].

Insights gained from applying the MLP approach for the case of Germany, in particular concerning aspects of technologies' resilience in regimes, can be seen just as well independent of their location. Since not only in Germany but also in other countries, technological developments are determined by a combination of different factors (incl. economic as well as social aspects), the experiences could be used to assess technological transition processes in other countries, too. The MLP approach allows an inclusion of aspects that are beyond economic and technological spheres. Thus, it is a suitable tool for identifying possible beginnings of phasing out processes as well as to assess possible phasing out pathways for other environment harming technologies (without being restricted to a specific country or technology).

\section{Endnotes}

${ }^{1}$ Besides the objective of climate change mitigation, the alliance strives for the prevention of adverse health effects of coal-use induced air pollution (e.g., respiratory diseases).

${ }^{2}$ Regarding water demand of power plants and the effects of global changes on this demand, see, e.g., [100] as well as [101].

${ }^{3}$ Following Rennings et al. [102], we define radical technology as a new technology that reflects a disruptive change over existing commercial technologies and "spurs the development of a new technological trajectory ([102]:335)."

${ }^{4}$ For more detailed information on priorities of targets set by political actors and on the impacts the priority setting had on the energy system, see, e.g., [23, 30, 50, 103].

${ }^{5}$ The "quasi-prohibition" of the construction of gasand oil-fired power stations resulted from the fixing of lower limits for the use of coal for electricity generation in the "Third law on coal for power generation" in combination with governmental supervision of investments in the power plants sector.

${ }^{6}$ The European Commission assessed the measure and decided that the aid is compatible with the Treaty on the Functioning of the European Union [55].

${ }^{7}$ There are several ongoing R\&D activities focusing on increasing the efficiency of coal-fired power plants. However, even if the generation of coal-fired power plants which are currently under development (advanced ultra-supercritical power plants) reach market maturity, the efficiency will be maximum up to $15 \%$ higher than the state-of-the-art coal-fired power plants of 2015 (see, e.g., [104]).

\section{Abbreviations}

BAT: Best Available Techniques; CCS: Carbon capture and storage;

CHP: Combined heat and power; EEG: Renewable Energy Sources Act; GHG: Greenhouse gas; IG BCE: Trade Union for Mining, Chemicals and Energy Industries; LCP BREF: BAT reference document for Large Combustion Plants; MLP: Multi-level perspective; NAPE: National Action Plan on Energy Efficiency; R\&D: Research and development; Verdi: United Services Trade Union

\section{Acknowledgements}

We thank Lisa Hanna Broska for her very helpful comments.

\section{Funding}

This research did not receive any specific grant from funding agencies in the public, commercial, or not-for-profit sectors.

\section{Availability of data and materials}

All datasets on which the conclusions of the manuscript rely are mentioned or presented in the main paper.

\section{Authors' contributions}

SV and PK conceived of the presented idea, developed the theory, and performed the computations. DR and TS aided in interpreting the results. All authors provided critical feedback and helped shape the research, analysis, and manuscript. All authors read and approved the final manuscript.

\section{Authors' information}

Dr. Stefan Vögele: Senior Scientist at Forschungszentrum Jülich, Institute of Energy and Climate Research - Systems Analysis and Technology Evaluation (IEK-STE), Germany

Paul Kunz: Phd-student at Forschungszentrum Jülich, Institute of Energy and Climate Research - Systems Analysis and Technology Evaluation (IEK-STE), Germany

Prof. Dr. Dirk Rübbelke: Chair of Economics, especially Resource Economics, at Technische Universität Bergakademie Freiberg, Germany

Theresa Stahlke: Phd-student at TU Bergakademie Freiberg, Schloßplatz 1, D-09596 Freiberg, Germany

Ethics approval and consent to participate

No human participants, human data, or human tissue have been involved.

Consent for publication

Not applicable

Competing interests

The authors declare that they have no competing interests.

\section{Publisher's Note}

Springer Nature remains neutral with regard to jurisdictional claims in published maps and institutional affiliations.

\section{Author details}

${ }^{1}$ Forschungszentrum Jülich, Institute of Energy and Climate Research Systems Analysis and Technology Evaluation (IEK-STE), 52425 Jülich, Germany. ${ }^{2}$ TU Bergakademie Freiberg, Schloßplatz 1, 09596 Freiberg, Germany.

Received: 19 January 2018 Accepted: 20 July 2018

Published online: 06 August 2018

\section{References}

1. Nelson RR, Winter SG (1982) An evolutionary theory of economic change. Belknap Press, Cambridge

2. Perez C, Soete $L$ (1988) Catching up in technology: entry barriers and windows of opportunity. In: Dosi G, Freeman C, Nelson R, Silverberg G, Soete $L$ (eds) Technical change and economic theory. Francis Pinter, London, pp 458-479

3. van den Bergh JCJM (2007) Evolutionary thinking in environmental economics. J Evol Econ 17:521-549 https://doi.org/10.1007/s00191-006-0054-0

4. Turnheim B, Geels FW (2013) The destabilisation of existing regimes: confronting a multi-dimensional framework with a case study of the British 
coal industry (1913-1967). Res Policy 42:1749-1767 https://doi.org/10.1016/j. respol.2013.04.009

5. Geels FW, Verhees B (2011) Cultural legitimacy and framing struggles in innovation journeys: a cultural-performative perspective and a case study of Dutch nuclear energy (1945-1986). Technol Forecast Soc Chang 78:910-930 https://doi.org/10.1016/j.techfore.2010.12.004

6. Araújo K (2014) The emerging field of energy transitions: progress, challenges, and opportunities. Energy Res Soc Sci 1:112-121 https://doi.org/10.1016/j.erss.2014.03.002

7. Foxon TJ, Hammond GP, PJG P (2010) Developing transition pathways for a low carbon electricity system in the UK. Technol Forecast Soc Chang 77: 1203-1213 https://doi.org/10.1016/j.techfore.2010.04.002

8. Geels FW (2005) The dynamics of transitions in socio-technical systems: a multi-level analysis of the transition pathway from horse-drawn carriages to automobiles (1860-1930). Tech Anal Strat Manag 17:445-476 https://doi. org/10.1080/09537320500357319

9. Geels FW (2002) Technological transitions as evolutionary reconfiguration processes: a multi-level perspective and a case-study. Res Policy 31:1257$1274 \mathrm{https}: / / \mathrm{doi} .0 \mathrm{rg} / 10.1016 / 50048-7333(02) 00062-8$

10. van Bree B, Verbong GPJ, Kramer GJ (2010) A multi-level perspective on the introduction of hydrogen and battery-electric vehicles. Technol Forecast Soc Chang 77:529-540 https://doi.org/10.1016/j.techfore.2009.12.005

11. Steinhilber S, Wells $P$, Thankappan S (2013) Socio-technical inertia: understanding the barriers to electric vehicles. Energy Policy 60:531-539 https://doi.org/10.1016/j.enpol.2013.04.076

12. Verbong GPJ, Geels FW (2010) Exploring sustainability transitions in the electricity sector with socio-technical pathways Technol Forecast Soc Chang 77:1214-1221 https://doi.org/10.1016/j.techfore.2010.04.008

13. Verbong GPJ, Beemsterboer S, Sengers F (2013) Smart grids or smart users? Involving users in developing a low carbon electricity economy. Energy Policy 52:117-125 https://doi.org/10.1016/j.enpol.2012.05.003

14. Rosenbloom D, Meadowcroft J (2014) The journey towards decarbonization: exploring socio-technical transitions in the electricity sector in the province of Ontario (1885-2013) and potential low-carbon pathways. Energy Policy 65:670-679 https://doi.org/10.1016/j.enpol.2013.09.039

15. Nelson RR (1994) The co-evolution of technology, industrial structure, and supporting institutions. Ind Corp Chang 3:47-63 https://doi.org/10.1093/icc/3.1.47

16. Markard J, Raven R, Truffer B (2012) Sustainability transitions: an emerging field of research and its prospects. Res Policy 41:955-967 https://doi.org/10. 1016/j.respol.2012.02.013

17. Mercure JF, Pollitt H, Chewpreecha U, Salas P, Foley AM, Holden PB, Edwards NR (2014) The dynamics of technology diffusion and the impacts of climate policy instruments in the decarbonisation of the global electricity sector. Energy Policy 73:686-700 https://doi.org/10. 1016/j.enpol.2014.06.029

18. Myhrvold NP, Caldeira K (2012) Greenhouse gases, climate change and the transition from coal to low-carbon electricity. Environ Res Lett 7:1-8 https://doi.org/10.1088/1748-9326/7/1/014019

19. Climate Analytics (2016) Implications of the Paris agreement for coal use in the power sector. Climate Analytics, Berlin

20. Powering Past Coal Alliance (2017) Powering past coal alliance declaration. https:/www.gov.uk/government/uploads/system/uploads/attachment_ data/file/660041/powering-past-coal-alliance.pdf. Accessed 19 Nov 2017

21. Schulz S, Schwartzkopff J (2015) G7 coal phase out: Germany--a review for Oxfam. www.e3g.org. Accessed 15 May 2017

22. BMWi (2018) Complete edition of energy data--data collection of the Federal Ministry for Economic Affairs and Energy http://www.bmwi.de. Accessed 20 May 2018

23. Leipprand A, Flachsland C (2018) Regime destabilization in energy transitions: the German debate on the future of coal. Energy Res Soc Sci 40 : 190-204 https://doi.org/10.1016/j.erss.2018.02.004

24. Federal Network Agency (2015) Kraftwerksliste Bundesnetzagentur http://www.bundesnetzagentur.de. Accessed 19 Nov 2015.

25. Statistik der Kohlenwirtschaft (2016) Zur Lage des Kohlenbergbaus in der Bundesrepublik Deutschland - Jahr 2015. Statistik der Kohlenwirtschaft, Herne/Cologne

26. Heinrichs HU, Markewitz P (2017) Long-term impacts of a coal phase-out in Germany as part of a greenhouse gas mitigation strategy. Appl Energy 192: 234-246 https://doi.org/10.1016/j.apenergy.2017.01.065

27. German Advisory Council on the Environment (2011) Pathways towards a 100\% renewable electricity system--special report. Erich Schmidt, Berlin
28. Ecofys Germany (2012) Kohleausstiegsgesetz - Verteilung der Reststrommengen und Folgenabschätzung für den Kohlekraftwerkspark. Greenpeace, Hamburg

29. Heinrichs HU et al (2017) Integrated assessment of a phase-out of coal-fired power plants in Germany. Energy 126:285-305 https://doi.org/10.1016/j. energy.2017.03.017

30. Renn O, Marshall JP (2016) Coal, nuclear and renewable energy policies in Germany: from the 1950s to the "Energiewende". Energy Policy 99:224-232

31. Rogge KS, Johnstone P (2017) Exploring the role of phase-out policies for low-carbon energy transitions: the case of the German Energiewende. Energy Res SocSci 33:128-137 https://doi.org/10.1016/j.erss.2017.10.004

32. Johnson N, Krey V, McCollum DL, Rao S, Riahi K, Rogelj J (2015) Stranded on a low-carbon planet: implications of climate policy for the phase-out of coal-based power plants. Technol Forecast Soc Chang 90:89-102 https://doi. org/10.1016/j.techfore.2014.02.028

33. Geels FW, Schot J (2007) Typology of sociotechnical transition pathways. Res Policy 36:399-417 https://doi.org/10.1016/j.respol.2007.01.003

34. Berry S, Davidson K, Saman W (2013) The impact of niche green developments in transforming the building sector: the case study of Lochiel Park. Energy Policy 62:646-655 https://doi.org/10.1016/j.enpol.2013.07.067

35. Bosman R, Loorbach D, Frantzeskaki N, Pistorius T (2014) Discursive regime dynamics in the Dutch energy transition. Environ Innov Soc Trans 13:45-59 https://doi.org/10.1016/.eist.2014.07.003

36. Fuenfschilling L, Truffer B (2014) The structuration of socio-technical regimes--conceptual foundations from institutional theory. Res Policy 43: 772-791 https://doi.org/10.1016/j.respol.2013.10.010

37. Penna CCR, Geels FW (2015) Climate change and the slow reorientation of the American car industry (1979-2012): an application and extension of the Dialectic Issue LifeCycle (DILC) model. Res Policy 44:1029-1048 https://doi. org/10.1016/j.respol.2014.11.010

38. Penna CCR, Geels FW (2012) Multi-dimensional struggles in the greening of industry: a dialectic issue lifecycle model and case study. Technol Forecast Soc Chang 79:999-1020 https://doi.org/10.1016/j.techfore.2011.09.006

39. Turnheim B, Geels FW (2012) Regime destabilisation as the flipside of energy transitions: lessons from the history of the British coal industry (1913-1997). Energy Policy 50:35-49 https://doi.org/10. 1016/j.enpol.2012.04.060

40. Geels FW (2014) Regime resistance against low-carbon transitions: introducing politics and power into the multi-level perspective. Theory Cult Soc 31:21-40 https://doi.org/10.1177/0263276414531627

41. Fuenfschilling L, Truffer B (2016) The interplay of institutions, actors and technologies in socio-technical systems--an analysis of transformations in the Australian urban water sector. Technol Forecast Soc Chang 103:298-312 https://doi.org/10.1016/j.techfore.2015.11.023

42. Kivimaa P, Kern F (2016) Creative destruction or mere niche support? Innovation policy mixes for sustainability transitions. Res Policy 45:205-217 https://doi.org/10.1016/j.respol.2015.09.008

43. Karltorp K, Sandén BA (2012) Explaining regime destabilisation in the pulp and paper industry. Environ Innov Soc Trans 2:66-81 https://doi.org/10. 1016/j.eist.2011.12.001

44. Mom G (2004) The electric vehicle: technology and expectations in the automobile. Johns Hopkins University Press, Baltimore

45. Möser K (2010) Fortdauer und Wiederkehr des Alten in der Technik. In: Böhn A, Möser K (eds) Techniknostalgie und Retrotechnologie. KIT Scientific Publishing, Karlsruhe, pp 17-40

46. Pavitt K (1972) Technology in Europe's future. Res Policy 1:210-273 https://doi.org/10.1016/0048-7333(72)90009-1

47. Raven R, Kern F, Verhees B, Smith A (2016) Niche construction and empowerment through socio-political work. A meta-analysis of six low-carbon technology cases. Environ Innov Soc Trans 18:164-180 https://doi.org/10.1016/.eist.2015.02.002

48. BMWi (2011) Research for an environmentally sound, reliable and affordable energy supply 6th Energy Research Programme of the Federal Government. Federal Ministry of Economics and Technology (BMWi), Berlin

49. BMWi (2015) Gabriel: Verständigung zur Braunkohle wichtiger Beitrag zur Erreichung der Klimaziele, Pressemitteilung 24.10.2015. Federal Ministry for Economic Affairs and Energy (BMWi), Berlin

50. BMWA (2005) 5th Energy Research Programme of the Federal Government Berlin. Federal Ministry for Economic Affairs and Labour (BMWA), Berlin

51. BMWi/BMU (2010) Energy concept for an environmentally sound, reliable and affordable energy supply. Federal Ministry of Economics and 
Technology (BMWi)/Federal Ministry for the Environment, Nature Conservation and Nuclear Safety (BMU), Berlin

52. Federal Environment Agency (2016) Umweltschädliche Subventionen in Deutschland ("environmentally harmful subsidies in Germany"). Dessau-Roßlau

53. Federal Ministry for the Environment; Nature Conservation; Building and Nuclear Safety (2014) Background paper: Climate Action Programme 2020 http://www.bmub.bund.de. Accessed 05 Mar 2016

54. European Commission (2013) A 2030 framework for climate and energy policies. Green Paper, COM(2013) 169 final. European Commission, Brussels

55. European Commission (2016) State aid SA.42536--Germany: closure of German lignite-fired power plants. European Commission, Brussels

56. BDEW (2015) BDEW-Strompreisanalyse August 2015. www.bdew.de. Accessed 03 Mar 2016

57. Greenpeace (2013) Schwarzbuch Kohlepolitik. http://www.greenpeace.de/sites/ www.greenpeace.de/files/publications/20130409-schwarzbuch-kohle.pdf

58. Verdi (2016) Energiewende - Sozialverträglicher Kohleausstieg ist machbar! https://ver-und-entsorgung.verdi.de. Accessed 15 May 2017

59. UBA (2015) National trend tables for the German Atmospheric Emission Reporting. German Environment Agency, Berlin

60. Storchmann K (2005) The rise and fall of German hard coal subsidies. Energy Policy 33:1469-1492 https://doi.org/10.1016/j.enpol.2004.01.006

61. Federal Environment Agency (2014) Environmentally harmful subsidies in Germany. https://www.umweltbundesamt.de/publikationen/ environmentally-harmful-subsidies-in-germany-2014. Accessed 15 May 2016

62. IEA (2016) RD\&D statistics http://www.iea.org/statistics/ RDDonlinedataservice/. Accessed 07 Mar 2016

63. Boehmer-Christiansen SA (1990) Energy policy and public opinion manipulation of environmental threats by vested interests in the UK and West Germany. Energy Policy 18:828-837 https://doi.org/10.1016/03014215(90)90062-9

64. Joas F, Pahle M, Flachsland C, Joas A (2016) Which goals are driving the Energiewende? Making sense of the German energy transformation. Energy Policy 95:42-51 https://doi.org/10.1016/j.enpol.2016.04.003

65. Verolme HJH (2016) Die internationale Klimagegenbewegung Unternehmenseinfluss in den Klimaverhandlungen. In: MISEREOR et al. (ed) Wirtschaft Macht Politik - Einfluss privatwirtschaftlicher Akteure in internationalen Politikprozessen. Aachen, pp 19-30

66. Greenpeace (2013) Schwarzbuch Kohlepolitik. Hamburg,

67. DNV GL - Energy (2016) Hard coal/lignite fired power plants in EU28--factbased scenario to meet commitments under the LCP BREF. 16-1213, Rev. 2 https://europeanclimate.org/wp-content/uploads/2017/06/16-1213-rev2DNV-GL-report-ECF-BREF-LCP2.pdf

68. energate (2017) EU verschärft Standards für Kraftwerksemissionen. http:// www.energate-messenger.de/news/173788/eu-verschaerft-standards-fuerkraftwerksemissionen. Accessed 18 Oct 2017

69. Rueter G (2017) Bald bessere Luft in Europa? DW Wissenschaft. https://www dw.com/de/bald-bessere-luft-in-europa/a-38618472. Accessed 17 Oct 2017

70. Hubik F, Flauger J (2016.) Der Aufstand der Kommunen. Handelsblatt

71. Roberts JCD (2017) Discursive destabilisation of socio-technical regimes: negative storylines and the discursive vulnerability of historical American railroads. Energy Res Soc Sci 31:86-99 https://doi.org/10.1016/j.erss.2017.05.031

72. Avril S, Mansilla C, Busson M, Lemaire T (2012) Photovoltaic energy policy: financial estimation and performance comparison of the public support in five representative countries. Energy Policy 51:244-258 https://doi.org/10. 1016/j.enpol.2012.07.050

73. Vattenfall (2016) Markets-Germany. https://corporate.vattenfall.com/aboutvattenfall/operations/markets/germany/. Accessed 20 June 2016

74. Quitzow L, Canzler W, Grundmann P, Leibenath M, Moss T, Rave T (2016) The German Energiewende--what's happening? Introducing the special issue. Util Policy 41:163-171 https://doi.org/10.1016/j.jup.2016.03.002

75. Lauber V, Jacobsson S (2016) The politics and economics of constructing, contesting and restricting socio-political space for renewables--the German Renewable Energy Act. Environ Innov Soc Trans 18:147-163 https://doi.org/ 10.1016/j.eist.2015.06.005

76. German Bundestag (2007) Gesetz zur Finanzierung der Beendigung des subventionierten Steinkohlenbergbaus zum Jahr 2018 (Steinkohlefinanzierungsgesetz). BGBI. I Bonn

77. Chowdhury S, Sumita U, Islam A, Bedja I (2014) Importance of policy for energy system transformation: diffusion of PV technology in Japan and Germany. Energy Policy 68:285-293 https://doi.org/10.1016/j.enpol.2014.01.023
78. IEA (2015) Projected costs of generating electricity. OECD/IEA, Paris

79. Geels FW et al (2016) The enactment of socio-technical transition pathways: a reformulated typology and a comparative multi-level analysis of the German and UK low-carbon electricity transitions (1990-2014). Res Policy 45:896-913 https://doi.org/10.1016/j.respol.2016.01.015

80. Johnstone P, Stirling A (2016) Comparing nuclear power trajectories in Germany and the UK: from 'regimes' to 'democracies' in sociotechnical transitions and discontinuities. SPRU https://doi.org/10.2139/ssrn.2744549

81. Kuckshinrichs W, Hake J-F (2015) Carbon capture, storage and use: technical, economic, environmental and societal perspectives. Springer, Cham

82. Burrow S (2017) Kohle ade! Übergang ins postfossile Zeitalter gerecht und fair gestalten. In: Friedrich-Ebert-Stiftung (ed) info 02/2017. Bonn,

83. Neslen A (2017) The end of coal: EU energy companies pledge no new plants from 2020. The Guardian. https://www.theguardian.com/ environment/2017/apr/05/the-end-of-coal-eu-energy-companies-pledge-nonew-plants-from-2020. Accessed 17 Oct 2017

84. European Commission (2016) Regulation of the European parliament and the council on the internal market for electricity, European Commission, Brussels

85. Schrader C (2016) Can Germany engineer a coal exit? Science 351:430-430 https://doi.org/10.1126/science.351.6272.430

86. Resch G, Liebmann L, Lamprecht M, Haas R, Pause F, Kahles M (2014) Phase out of nuclear power in Europe--from vision to reality. Vienna University of Technology, Institute of Energy systems and electric drives, energy economics group (EEG), Vienna

87. Statistisches Bundesamt (2016) GENESIS online database--water (GENESIS online database - Wasser) https://www.destatis.de. Accessed 08 Aug 2016

88. Wechsung F, Hartje V, Kaden S, Venohr M, Hansjürgens B, Gräfe P (eds) (2014) The River Elbe and Global Change. An integrative View. (Die Elbe im globalen Wandel. Eine integrative Betrachtung.). Konzepte für die nachhaltige Entwicklung einer Flusslandschaft, Bd. 9. Weißensee Verlag, Berlin

89. 50 Hertz Transmission $\mathrm{GmbH}$, Amprion $\mathrm{GmbH}$, TenneT TSO GmbH, TransnetBW GmbH (2016) Grid development plan 2025, version 2015, first draft. http://www.netzentwicklungsplan.de. Accessed 08 Aug 2016

90. Bruninx K, Madzharov D, Delarue E, D'Haeseleer W (2013) Impact of the German nuclear phase-out on Europe's electricity generation--a comprehensive study. Energy Policy 60:251-261 https://doi.org/10.1016/j. enpol.2013.05.026

91. Edberg K, Tarasova E (2016) Phasing out or phasing in: framing the role of nuclear power in the Swedish energy transition. Energy Res Soc Sci 13:170179 https://doi.org/10.1016/j.erss.2015.12.008

92. IGBCE (2015) Koalitionssauschuss legt künftige Energiepolitik fest Medieninformation XIX/36 www.igbce.de. Accessed 15 May 2017

93. Yilmaz HÜ, Bchini Q, Keles D, Hartel R, Wolf F, Mikulić M, Jakšić D (2016) Impacts of a UK and German coal phase-out on the electricity mix and $\mathrm{CO}_{2}$ emissions in Europe. INSIGHT-E, Karlsruhe

94. ABB (2016) Impacts of Dutch coal plants phase out. http:IVbestanden. scriptacommunicatie.n/luniper/ABB-Impacts of a Dutch Coal plants phaseout.pdf. Accessed 15 May 2017

95. Climate Analytics (2017) Coal phase out in the European Union. http://climateanalytics.org/hot-topics/eu-coal-phase-out.html. Accessed 17 Oct 2017

96. BMWi (2018) Bundeskabinett setzt Kommission "Wachstum, Strukturwandel und Beschäftigung" ein, press release 06.06.2018, Federal Ministry for Economic Affairs and Energy (BMWi), Berlin

97. Edenhofer O, Knopf B, Luderer G, Steckel J, Bruckner T (2011) More heat than light? On the economics of decarbonisation. In: John KD, Rübbelke $D$ (eds) Sustainable energy. Routledge, Abingdon/New York, pp 70-108

98. Rübbelke D, Vögele S (2013) Effects of carbon dioxide capture and storage in Germany on European electricity exchange and welfare. Energy Policy 59: 582-588 https://doi.org/10.1016/j.enpol.2013.04.011

99. Green R, Staffell I (2016) Electricity in Europe: exiting fossil fuels? Oxf Rev Econ Policy 32:282-303

100. Koch H, Vögele S (2009) Dynamic modelling of water demand, water availability and adaptation strategies for power plants to global change. Ecol Econ 68:2031-2039 https://doi.org/10.1016/j.ecolecon.2009.02.015

101. van Vliet MTH, Vögele S, Rübbelke D (2013) Water constraints on European power supply under climate change: impacts on electricity prices. Environ Res Lett 8 https://doi.org/10.1088/1748-9326/8/3/035010

102. Rennings K, Markewitz P, Vögele S (2013) How clean is clean? Incremental versus radical technological change in coal-fired power plants. J Evol Econ 23:331-355 https://doi.org/10.1007/s00191-010-0198-9 
103. German Bundestag (1991) Protecting the earth: a status report with recommendations for a new energy policy. Third report of the Enquete Commission of the 11th German Bundestag--preventive measures to protect the earth's atmosphere. Dt. Bundestag, Bonn

104. IEA (2012) Technology roadmap: high-efficiency, low-emissions coal-fired power generation. OECD/IEA, Paris

105. 50Hertz Transmission GmbH, Amprion GmbH, TenneT TSO GmbH, GmbH T (2018) Grid development plan power. https://www.netzentwicklungsplan.de/. Accessed 20 May 2018

Submit your manuscript to a SpringerOpen ${ }^{\mathcal{O}}$ journal and benefit from:

- Convenient online submission

- Rigorous peer review

- Open access: articles freely available online

- High visibility within the field

- Retaining the copyright to your article

Submit your next manuscript at $\boldsymbol{\nabla}$ springeropen.com 